\title{
Voluntary intake and feeding behaviour in relation to digestive function and body composition in normal and double-muscled Belgian-Blue young bulls
}

\author{
R Baumont 1, F Dehareng 3, J Jamot 1, A Détour 1, Rt Jailler 2, \\ Rd Jailler 2, Y Geay 2, AG Deswysen ${ }^{3}$ \\ IINRA Station de Recherches sur la Nutrition des Herbivores; 2INRA Laboratoire Croissance et \\ Métabolismes des Herbivores, 63122 St-Genès-Champanelle, France ; 3UCL Faculté des Sciences \\ Agronomiques, Unité de Génétique, 1348 Louvain-la-Neuve, Belgique
}

Double-muscled Belgian-Blue bulls are known to have lower voluntary intake (VI) and better feed conversion ratio than normal bulls (Hanset et al, 1987, Génét Sél Evol, 19, 2, 225-248). The low VI of double-muscled animals was analysed through feeding behaviour, digestive function and body composition.

Six normal (N) and 6 double-muscled (D) young bulls were compared at 9 months of age $(270 \mathrm{~kg})$. Bulls received $40 \mathrm{~g} \mathrm{DM} / \mathrm{kg} \mathrm{BW} 0.75$ of pelleted concentrate $(57.5 \%$ maize) and grass hay (58.6\% NDF) ad libitum (10\% refusals). Hay and concentrate were fed in two equal portions at 9 am and $15 \mathrm{pm}$ for hay, and at 10 am and $16 \mathrm{pm}$ for concentrate. After 2 weeks of adaptation, VI, kinetics of intake and jaw movements were recorded over 5 days (Baumont et al, 1990, J Agric Sci, 115, 277284). Afterwards, the bulls were fed at $95 \%$ of the determined VI with $50 / 50 \%$ hay/concentrate ratio. Digestibility, nitrogen retention and retention times of Eu-labelled hay and $\mathrm{Yb}$ labelled concentrate particles were measured over 10 days during which feeding behaviour was recorded over 5 days. Then, energy expenditure was measured by indirect calorimetry ( 7 days, Vermorel et al, 1994, Proc XIIlth Symp on Energy Metabolism, EAAP publ 76 ). Bulls were slaughtered 4 or 6 days later on.
$\mathrm{VI}$ in $\mathrm{D}$ bulls was $10 \%$ lower than in $\mathrm{N}$ bulls and was associated with a lower rate of intake (RI) and a higher number of meals. $R I$ in $D$ bulls was significantly lower during both hay meals following distributions (14.3 vs $17.0 \mathrm{~g}$ $\mathrm{DM} / \mathrm{min}, \mathrm{P}=0.013$ ) and during concentrate meal at $10 \mathrm{am}(77.1$ vs $95.7 \mathrm{~g} \mathrm{DM} / \mathrm{min}$, $P=0.041$ ). Differences in feeding behaviour were similar during digestibility period. Drymatter digestibility was similar in $N$ and $D$ bulls $(69.6 \%)$, as also total retention time of hay $(48.7 \mathrm{~h})$ and concentrate $(32.0 \mathrm{~h})$. Empty weight of digestive tract $(47.3$ vs $56.8 \mathrm{~g} / \mathrm{kg}$ empty $\mathrm{BW}, \mathrm{P}=0.001$ ) and rumen ( $15.6 \mathrm{vs}$ $18.3 \mathrm{~g} / \mathrm{kg}$ empty $\mathrm{BW}, \mathrm{P}=0.003$ ) were lower in D bulls.

These preliminary results show that lower $\mathrm{VI}$ in $\mathrm{D}$ bulls is related to a lower motivation to eat (lower RI) which might be explained by lower energy gains (24.8 vs $49.3 \mathrm{kcal} / \mathrm{d} / \mathrm{kg}$ BW0.75, $P=0.0004$ ) due to slightly higher protein accretion ( 81.2 vs $72.8 \%$ muscles in the carcass, $P=0.003$ ) but much lower lipid gains (4.4 vs $9.9 \%$ adipose tissues, $P=0.007$ ). In addition, physical limitation of hay intake should be more effective in $D$ bulls which have a reduced rumen size and therefore tend to increase daily number of meals.

$\begin{array}{lccc} & \mathrm{N} & \mathrm{D} & \text { P value } \\ \text { Voluntary Intake }(\mathrm{g} \mathrm{DM} / \mathrm{kg} \mathrm{BW} 0.75 / \mathrm{d}) & 88.6 & 79.6 & 0.005 \\ \text { Hay intake }(\mathrm{g} \mathrm{DM} / \mathrm{kg} \mathrm{BW} \text { 0.75/d) } & 47.4 & 40.5 & <0.001 \\ \text { Rate of intake }(\mathrm{g} \mathrm{DM} / \mathrm{min} / \mathrm{d}) & 22.7 & 19.6 & 0.025 \\ \text { Number of meals } / \mathrm{d}) & 11.0 & 12.7 & 0.080\end{array}$

*: "genotype" effect in the analysis of variance. 